\title{
The Money that Never Sleeps: Bureaucratic Movement and Vote Buying Dynamics in Bolaang Mongondow, North Sulawesi ${ }^{1}$
}

\author{
Nono Stevano Agustinus Sumampouw
}

Received: 7 August 2017 | Accepted: 12 March 2018 | Published: 26 March 2018

\begin{abstract}
Financial gifts have been an important, albeit not the only, factor in gathering voter support during regional elections in Indonesia. This article seeks to explore the 'dawn attacks' (serangan fajar) of vote buying in Bolaang Mongondow Regency, a practice that is socially required to gain votes during regional elections. Furthermore, this article explores how vote buying through personal finances and bureaucratic mobilisation has become a dominant factor in regional elections, far more important than institutional resources and conservative political instruments such as political parties. Despite Bolaang Mongondow being a region expected to offer little political and economic potential for vote buying at a massive scale - this regency is far from the national political mainstream, and most residents live quite prosperous and could fulfil their basic needs - these 'dawn attacks' have continued on a massive scale during regional elections. Furthermore, this article explains the context, background, and rationale underlying the practice of vote buying as well as the main actors involved. This article also offers an empirical comparative and theoretical perspective regarding vote buying.
\end{abstract}

Keywords: Bolaang Mongondow, 'dawn attacks', vote buying, bureaucracy

\section{Introduction}

Vote buying is an important phenomenon in present-day electoral politics, particularly in developing countries (Hicken, Leider, Ravanilla, Yang, 2016). Latin America, for instance, countries with varying degrees of natural resources and diverse ideologies and democracies have all seen vote buying used for electoral purposes (Hoepers, 2012; Diaz-Cayeros, Estévez, \& Magaloni, 2016; Brusco, Nazareno, Stokes, 2004; Serra, 2016). Similar use of vote buying

\footnotetext{
This article and research were completed with the financial support of the 2017 Local Elections research project, a collaboration between Australia National University and Polgov. The researcher would also like to thank Mulyadi Pontororing, who supported the research proecess as research assistant.
} 
in elections has been noted in South Asian countries such as India (Bjorkman, 2013; Rojo et al., 2016), as well as Southeast Asian countries such as the Philippines (Cruz, Keefer, Labonne, 2016; Hicken, et al., 2016).

Various journalistic reports, such as in Banten (Deslatama, February 9, 2017; Tempo, February 19, 2017), as well as academic studies (Aspinall \& Sukmajati, 2015; Aspinall \& Sukmajati, 2016; Aspinall, et al., 2017), have explored the practice of vote buying in various parts of Indonesia. During the 2014 elections, the practice of vote buying was found in all parts of Indonesia, with one common form being 'dawn attacks (serangan fajar) in which money was distributed to potential voters in the early hours of election day (Aspinall \& Sukmajati, 2015; Aspinall \& Sukmajati, 2016).

This phenomenon was also noted during the simultaneous elections held in 101 Indonesian provinces/regencies/cities on 15 February 2017, which demonstrated the diverse political dynamics of each region. These diverse dynamics, including interpretations and logics, are influenced by the different natural resources, cultures, and regional economies involved.

Despite being shadowed by the media coverage of the Jakarta gubernatorial elections, the regency of Bolaang Mongondow was reported to have the second highest amount of vote buying in Indonesia (following Jakarta). ${ }^{2}$ This region is relatively isolated from the national stage, geographically, politically, socially, and academically, as indicated by the minimal coverage of the regency in mass publications; only one national publication covered Bolaang Mongondow (and this after the election), namely the arrest of Aditya Anugerah Moha (a member of the Indonesian parliament from the Partai Golongan Karya [Functional Groups Party, Golkar]) for bribing the head of the North Sulawesi Superior Court to free

2 It has been reported that, in the Jakarta Gubernatorial Election, 'dawn attacks' in the amount of Rp. 500,000/vote were distributed. Meanwhile, this research programme has found that, in Gunung Kidul and some parts of Central Java, the amount given was only Rp. 100,000/vote. 
his mother, who had been charged with corruption. At a glance, the amount spent on vote buying in Bolaang Mongondow appears anomalous given the economic and political potential of the region. Reports from the field has verified a highest rate of Rp. 300,000 being spent per vote, given the day before voting. Meanwhile, Rp. 200,000 was spent per vote on average, excluding the money given to participants in campaign events (Junaidi Amra, interview, January 25, 2017; Pitres Sombowadile, Interview, January 27, 2017; Fauzi Permata, Interview, March 1, 2017; Nayodo Kurniawan, interview, February 19, 2017).

In describing the process of distributing money, this article also attempts to examine how the vote-buying process in Bolaang Mongondow differed from the process in other regions, not only in total amount spent but also in blatancy. This article also attempts to explore the role and mobilisation of bureaucrats and the bureaucracy in these 'dawn attacks' (specifically) and vote buying (in general). Where previous examinations of vote buying in Indonesia have focused on its practice in specific administrative units such as provinces and regencies (Aspinall \& Sukmajati, 2016; Aspinall, 2017; Cruz et al., 2016; Serra, 2016; Hicken et al., 2016), this article also attempts to understand this phenomenon as the exploitation of bureaucratic linkages between regencies/cities and provinces, rather than simply stemming from political parties.

Generally, this article will examine the dynamics of vote buying in Bolaang Mongondow Regency, North Sulawesi, during campaigning and voting in the 2017 regional elections. The discussion within this article is divided into several sections, focusing on the vote buying process, i.e. the mobilisation of money and political support, including the bureaucracy, to gain voter support; the source and use of money, including its relevance and rationalisation within the region's political networks and (potential) resources; how these dynamics are positioned in the context of local and national politics, and the theoretical positioning of this case in the general literature on vote buying. 


\section{An Exploration of the Theory and Literature on Vote Buying}

Conceptually, vote buying develops from clientelism and patronage, and involves the distribution of resources to constituents to gain their votes. We can see this concept defined as "the exchange of money, service or goods for votes (Schaffer, 2008)" (as cited in Aspinall, 2017, p.3); "the exchange of private goods for votes during electoral campaign (Ocantos, 2014)" (as cited in Aspinall, 2017, p. 3 ); and "the proffering to voters of cash or (more commonly) minor consumption goods by political parties, in office or in opposition, in exchange for the recipient's vote" (Brusco et al., 2004, p. 67). The most relevant definition for examining the relevance of this practice and its goals, however, is "the pre-electoral provision of gifts of goods or money, aimed at persuading recipients to vote in a particular way, to turn out to vote, or not to vote at all (Hicken, 2011; Schaffer and Schedler, 2007; Nichter , 2008)" (as cited in Cruz et al. 2016, p. 4).

Vote buying is practiced within a political system, particularly through party and government agents with their own calculations of political possibilities and regulations. Because resources and materials are necessary, agents in the practice of vote buying are primarily mature conventional political parties (Aspinall, 2017, p. 23; Brusco et al., 2004). As such, mobilising the bureaucracy is important, and is often seen as benefiting incumbent candidates (Cruz et al., 2016; Hicken et al., 2016; Serra, 2016).

As a political process, vote buying is illustrated as a transaction in which money or material goods are exchanged for votes. However, the case of Indonesia has shown that this practice is underlain by socio-cultural factors (Aspinall et al., 2017). In Indonesia, what has been called the social networks machine has been more effective than conventional political machines such as political parties (Aspinall, 2017, p. 2).

At the same time, vote buying has shown greater efficiency areas with high population densities and levels of poverty (Diaz- 
Cayeroz, 2016.; Brusco, et al., 2004; Hoepers, 2012; Rojo et al., 2016: Bjorkman, 2013; Serra, 2016). In Indonesia, this argument can be seen in the case of Jakarta, a densely populated city with high levels of poverty in certain settlements (Dewi, Harjanto, \& Purba, 2016).

Various long-ignored aspects of vote buying in an Indonesian context are examined in this article. For example, methodologically, many studies of vote buying in Indonesia have taken the 2014 legislative elections as their cases (i.e. Aspinall \& Sukmajati, 2016; Aspinall, et al., 2017). Consideration must also be given to the administrative division of electoral regions at the national, provincial, and regency/municipality level, which are divided into various constituencies down to the district level, which clearly affects the number of voters and the area covered.

\section{Geo-Demographic Context, Local Politics, and Election Results}

Bolaang Mongondow is located a four-hour drive from Manado, the capital of North Sulawesi. This regency has the largest land area in North Sulawesi. The largest rice producer of the province, Bolaang Mongondow has expansive rice fields in its highlands and lowlands, including the north coast. It also hosts the productive forest of the Bogani Nani Wartabone National Park.

A number of mines are also located in the regency, managed by companies or individuals; the latter are better known as 'folk mines' (pertambangan rakyat). Such mines are located primarily in the Lolayan and Dumoga regions. Meanwhile, continuances of the companies PT. Newmont Minahasa Raya and PT. Avocet are located along the Bolaang Mongondow - East Bolaang Mongondow border.

Bolaang Mongondow Regency covers an area of 351,747 $\mathrm{km}^{2}$. Parts of the regency have been the basis for new administrative districts, including North Bolaang Mongondow, Kotamobagu Municipality, South Bolaang Mongondow, and East Bolaang 
Mongondow. The regional capital, once located in Kotamobagu, has been moved to Lolak since the former was made as an independent municipal administrative entity. However, the centre of social and economic activity in Greater Bolaang Mongondow remains Kotamobagu. A local anecdote holds that "the heart of regional elections in Bolaang Mongondow is in Kotamobagu".

Map 1.

Bolaang-Mongondow Regency before "The Pemekaran" and Regencies/Municipal after "The Pemekaran"
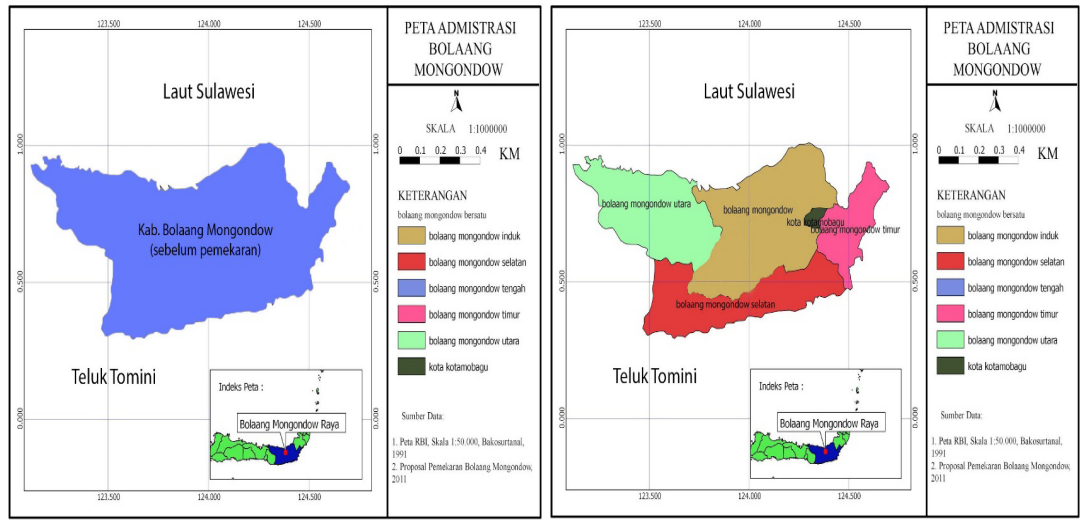

Source: Proposal Pembentukan Prov. Bolaang Mongondow Raya with less modification

According to data from Statistics Indonesia, the population of Bolaang Mongondow in 2015 was 233,189. Meanwhile, the 2014 population density of 64 people per $\mathrm{km}^{2}$ indicates that Bolaang Mongondow is not densely populated. The availability of land (and sea) may be utilised effectively by people of various social levels and occupations. This is reinforced by the fact that the majority of land in the regency remains owned individually or by families. Generally, the land in this regency is fertile, and given the natural and social conditions residents are generally able to ensure their subsistence and even fulfil their primary and secondary needs. Among the people of North Sulawesi, the people of Bolaang Mongondow are known for being consumptive in their material and social activities, even 
though its 2016 human development index of 65.73 was neither the best in North Sulawesi nor above the national average (69.55). This socio-economic situation is important for understanding the logics involved in vote buying in the region.

Although the majority of residents in North Sulawesi are Protestants of Minahasa heritage, Islam is the majority religion in Bolaang Mongondow, while the Mongondow are the majority ethnic group. Data from Statistics Indonesia, based on the 2010 census, indicates that 131,013 residents $( \pm 60 \%$ of the regency's residents) are categorised as "Other North Sulawesi Ethnicities"; assumedly, this is predominantly ethnic Mongondow, with a small number of ethnic Sangihe-Talaud. Meanwhile, the province is home to 43,640 Christians of ethnic Minahasa heritage $( \pm 20 \%$ of the population). The remainder are of various heritage groups, particularly Balinese transmigrants who have long lived in Dumoga, but also including ethnic Javanese, Bugis, Gorontalo, etc. Dumoga has a strong influence on political processes in Bolaang Mongondow, as indicated by all potential deputy regents being from Dumoga, the population of which is predominantly Minahasa and Christian.

The political power of ethnicity and religion in Bolaang Mongondow can be surmised from the family names of the thirty members of local parliament. At least $10( \pm 33 \%)$ can be identified as Christians of Minahasa heritage. The head of the regional parliament is of Minahasa heritage and serves as the men's leader for the Christian Evangelical Church in Bolaang Mongondow. He was one of the main supporters of Yasti and her running mate Yanni Tuuk (Candidate Pair No. 1), particularly to collect the support of the Christian communities in Dumoga (informant, interviews, February 27, 2017; informant, interview, March 2, 2017). At least three members of parliament $(10 \%)$ are of Hindu Balinese heritage. The remainder, some 17 people $( \pm 57 \%)$ represent the Muslim community, consisting of ethnic Mongondow, Javanese, and Arabs; the region is also home to a small Chinese minority population.

The candidacies of regional leaders can be indicative of 
whether or not population is an influential factor in regional elections. As they appeared on the ballot in the 2017 regional election, the candidates were: (1) Yasti Supredjo Mokoagow and Yanni Tuuk, backed by five parties-Partai Demokrat IndonesiaPerjuangan (Indonesian Democratic Party of Struggle, PDIP), Partai Amanat Nasional (National Mandate Party, PAN), Partai Kebangkitan Bangsa (National Awakening Party, PKB), Partai Keadilan Sejahteran (Prosperous Justice Party, PKS), and Partai Nasdem (Nasional Democratic Party, Nasdem);-(2) Salihi Mokodongan and Jefry Tumelap, backed by three parties-Partai Gerakan Indonesia Raya (Great Indonesia Party, Gerindra), Partai Golongan Karya (Functional Groups Party, Golkar), and the Partai Demokrat (Democratic Party, Demokrat). Each candidate for regent was a Muslim of Mongondow heritage, while their running mates were Protestants of Minahasa heritage from Dumoga.

Noting this demographic configuration and mapping of supporting party coalitions, it may be surmised that ethnicity and religion are considered as important factors in the selection of potential candidates. Such candidates were selected based on the perception that religious and ethnic representation was necessary. However, in the winning of elections, this was not the main factor. The high degree of social fragmentation, without any truly dominant specific ethnic or religious group, meant that they could not be used as the sole instrument for mobilising support. Rather, there was the view that 'rational' considerations, instead of such 'emotional' or 'ideological ones', were needed for electoral victory.

Ethnic and religious issues were still exploited to erode support for Yasti and Yanni. One leaflet claimed that Yasti was a 'migrant' because her father was Javanese; that her family had many Christian members of Minahasa heritage; that she wore a veil solely for political purposes and was not worthy of the title hajjah (a women/lady who has gone on the hajj pilgrimage). The leaflet also claimed that Yasti could potentially be imprisoned by the Corruption Eradication Commission, leaving her Minahasan-Christian deputy 
to lead the predominantly Muslim and Mongondow residents of the region, a situation exacerbated by the leader of the local parliament also being a Christian of Minahasa heritage (Mulyadi, interview, March 19, 2017). ${ }^{3}$ However, these rumours were clearly not effective, as these candidates won the election.

\section{Vote Buying in Regional Elections in (Greater) Bolaang Mongondow}

Since at least 2011, the people of North Sulawesi have viewed the residents of (Greater) Bolaang Mongondow as the most pragmatic. This can be seen in the rampant use of 'dawn attacks' during elections, both legislative and executive. ${ }^{4}$ Reports indicate that the amount spent on vote buying in Bolaang Mongondow was the highest in North Sulawesi. However, internal information (Candidate Campaign Teams, January 27, 2017) indicates that the buying and selling of votes had begun as early as 2001, when Marlina Moha and Siahaan of the Golkar Party were elected regent/deputy regent. In the 2001 election, these candidates-despite being firstterm members of local parliament-were able to defeat Djelantik Mokodompit, a member of the national parliament by buying the support of local members of parliament and Golkar Administrators, both at the provincial level and at the regency level.

Since 2011, widespread 'dawn attacks' in Greater Bolaang Mongondow have received widespread coverage, at least in local print media and stories. The amount has ranged from Rp. 100,000 to Rp. 1,000,000 per votes, and often been paired with goods or foods. This has been noted in various executive and legislative elections in the region, including in Bolaang Mongondow, Kotamobagu, and East Bolaang Mongondow.

In the 2011 election in Bolaang Mongondow, the victory of candidates Salihi Mokodongan and Yanni Tuuk was entirely

The source was identified through evidence from the Election Monitoring Committee of Bolaang Mongondow, as well as an interview with Mulyadi Pontororing.

4 For instance: Hamja (2017) ; Norma Akan Ambil. (2017). 
unexpected, even the day before voting. Surveys and predictions suggested that they would finish last in the election, behind all other candidates. However, 'dawn attacks' were rampant, with the lowest value being Rp. 100,000/vote-financial support for which was collected from Yasti Soepredjo Mokoagouw, Olly Dondokambey, and Rudi Wowor-. This was given together with freshly caught fish from Salihi's fishery. Some of this money was reportedly slipped into the mouths of the fish, a story that became popular among local residents. Recognising the educational background of Salihi, who did not finish regular schooling but rather completed elementary, junior high, and senior high school equivalency tests (in Indonesian, Paket $A, B$ and C) (Pitres Sombowadile, interview, January 27, 2017), some local residents proclaimed: "even a monkey can become regent of Bolaang Mongondow if it has money" (Pitres Sombowadile, ibid; Junaidi Amra, ibid). ${ }^{5}$

Meanwhile, in the 2013 regional election in Kotamobagu, 'dawn attacks' of up to Rp. 1,000,000/vote were recorded. According to the plaintiffs who brought this case to the Constitutional Court, the judges stated that in no prior case of 'dawn attacks' had such values been noted (Junaidi Amra, ibid). Such amounts were also recorded in the 2014 legislative elections (Sumampouw, 2016b). Tensions over 'dawn attacks' continued in the electoral contestation in Greater Bolaang Mongondow. In East Bolaang Mongondow, Sahrul Mamonto - fully backed by Yasti (DPR-RI) and Tatong Bara (i.e. the mayor of Kotamobagu) - ran against Sehan Landjar (the incumbent regent). Sehan ultimately emerged victorious, despite spending a minimal amount on 'dawn attacks'. Because entry to East Bolaang Mongondow was limited to the north, east, and south, the distribution of money to voters by Sahrul Mamonto could be recorded by local media (Mulyadi Pontororing, interview, February 10, 2017; Fauzie Permata, ibid). ${ }^{6}$

Original: hele yaki boleh jadi bupati (kepala daerah) di Bolmong (Raya) kalo ada doi. Coverage of this can also be found in Eyang Sebut Ismail (2015). 
This electoral contest ultimately influenced the regional election in Bolaang Mongondow, as Sehan Landjar was ultimately made head of PAN's North Sulawesi branch and began manoeuvring against Yasti and Tatong Bara. In the Bolaang Mongondow regional election, Yasti received the backing of PAN's central committee. However, Sehan Landjar, the provincial committee's head, gave his support to Salihi Mokodongan and Jefry Tumelap (Junaidi Amra, ibid, January 27, 2017; Fauzie Permata, ibid) ${ }^{7}$. This influenced the use of resources, with the regional leader providing support to certain candidates and supporting their vote buying in Bolaang Mongondow.

Based on the explanation above, the use of vote buying in political events such as regional and legislative elections, as well as sangadji (village chiefs) in (Greater) Bolaang Mongondow can be seen to be widely practiced and recognised by residents, election officials, and law enforcement. Not using such 'dawn attacks' would not be sufficient in Bolaang Mongondow to ensure electoral victory.

\section{Vote Buying and Money Mobilisation}

In Bolaang Mongondow, it is impossible to separate election (periods) and vote buying. Such money is perceived as candidates' 'repaying the favour' of voting for them, particularly in elections that directly involve the populace, such as those for regents, mayors, and members of (national/local) parliament. As a result, during presidential elections, voter turnout decreases sharply because of the lack of vote buying (Nayodo Kurniawan, ibid). Before the 2017 election, it was predicted that vote buying would be minimal, merely a 'complement' to the elections process, as one pair of candidates

Rumours suggest that this recommendation was made because Yasti was not allied with Zulkifli Lubis (the leader of PAN's central committee) and had lost influence at the national level. As such, by supporting Yasti, Bara Hasibuan - a member of PAN's central committee, under Zulkifli Lubis - would replace Yasti; as such, whichever candidate won, it would be seen as a victory for PAN. Locally, such a tactic is known as "ceke dua pintu", or "bainjang di dua tampa", meaning to benefit no matter the outcome. See also Pilkada Bolaang Mongondow (2017). 
was truly dominant in surveys. However, this was not reflected in the political psychology of the populace:

"This time, the Croupier (Yasti) came directly, so of course there would be dawn attacks." (Junaidi Amra, interview, January 25, 2017) ${ }^{8}$

As such, it can be understood that residents of Bolaang Mongondow viewed 'dawn attacks' on a massive scale as being socially acceptable. At the same time, there was recognition that Yasti had provided the political capital and 'dawn attacks' that had enabled Salihi to be elected in the previous election. As a result, there was no doubt that vote buying would occur in Bolaang Mongondow. Despite dominating surveys, Yasti and Yanni felt that they required 'dawn attacks' to ensure their victory (Nayodo Kurniawan, ibid; Junaidi Amra, ibid; Pitres Sombowadile, ibid). At this point, they adapted to the political tendencies of the populace. They recognised that the previous regional election was lost by candidates expected to win, and the underdogs Salihi and Yanni were ultimately elected because of their massive use of 'dawn attacks'.

In the Bolaang Mongondow regional election, club goodsin this case, the giving of food items (such as soda, rice, flour, and butter) for holidays - was distributed long before the campaign period as a means of gathering constituents' support and enabling them to judge the candidates' financial capacity. As such, vote buying was commodified for election materials. Yasti and Yanni never made an open promise to reject money politics, unlike their opponents Salihi Mokodongan and Jefry Tumelap, who instead attempted to gain voter support through a cultural approach. In this context, money politics was understood by candidates, campaign teams, and local residents as limited to 'dawn attacks'. The distribution of club goods and other materials, meanwhile, was understood as silaturahmi (hospitality), something evident in

\footnotetext{
Original: ini komang bandar yang turun langsung jadi pasti musti bayar.
} 
the formal and non-formal relationships between candidates and constituents through their campaign teams. Among residents, this was understood symbolically as three things: an invitation to vote, a sign of gratitude, and a holiday greeting. This occurred in Dumoga over Christmas, as noted in the following interview:

"For Christmas, Yanni Tuuk gave 5 kilograms of rice, sugar, flour, and butter, as well as 1.5 litre bottles of Coca-Cola, Fanta, and Sprite to each family. Likewise, Jefry distributed 3 kilograms of rice, with the remainder like Yanni. They said this was not to buy votes, but only a way of saying 'Merry Christmas' and sharing their blessings. But yes, implicitly, they were asking us to vote." (Ratih Rintang and Olvi Agow, interview, February 17, 2017). ${ }^{9}$

As such, vote buying was conducted simultaneously as a process intended to access constituents. As such, the total amount spent on vote buying was not only considered during 'dawn attacks', but also as an accumulative value. Money distributed was calculated per voter, while goods distributed were calculated per household.

The practice of vote buying continued through every stage, including dialogue. A minimum of Rp. 100,000/each was distributed to participants, identified as being for transportation. This amount was selected to avoid violating the General Election Commission's rule that no more than Rp. 110,000 could be given to cover transportation costs (informant, interviews, February 27, 2017; informant, interview, January 26, 2017; Nayodo Kurniawan, ibid). Although denied by campaign teams, (Ismail Dahab, interview, March 3, 2017) calculations indicate that a massive amount was spent during this period (ibid). ${ }^{10}$ This is logical, given residents' fixation on participating in campaign activities to access money. Where there was a campaign, there was money.

9 Original: Waktu Natal, Yanni kase $5 \mathrm{~kg}$ beras, gula, terigu, mentega deng masing-masing 1,5 Liter Coca-cola, Fanta deng Sprite tiap keluarga. Bagitu le Jefry ada kase $3 \mathrm{~kg}$ beras deng sama deng Yanni. Dorang bilang ini bukang voor beli suara, maar memang voor samua tanda selamat Natal deng berbage berkat. Maar katu so ba sein no.

10 The informant explained that, of more than 200 villages, no fewer than 150 hosted dialogic 
The phrase 'transport money' was most commonly used by Yasti and Yanni. This money was not only given during 'closed' campaigning, but also during open campaigning and fundraising. An amount of Rp. 2 billion was reportedly spent by Yasti and Yanni during their open campaign, (informant, interviews, January 26, 2017; Abdul Kadir Mangkat, interview, February 28, 2017) and their coordinators distributed Rp. 100,000 to each participant (informant, interviews, February 27, 2017; informant, interview, Januari 30, 2017).

The peak of the 'dawn attacks' occurred on malam bakupas, a festival held the day before voting, when money was distributed to potential voters. On this night, an abundance of food and music was made available by campaign team members in their villages (Junaidi Amra, ibid; Ratih Rintang and Olvi Agow, ibid). Many residents, from all walks of life, waited outside their homes to wait for the money distributed by campaign team members (informant, interview, February 27, 2017). This clearly shows that local residents recognised that money was being mobilised for elections. Furthermore, in the days before the election, many rumours about the 'market rate' for votes were spread. Several print and internet media, such as the Manado Post, Tribun Manado, and Radar Manado recorded rates of $\mathrm{Rp}$. 200,000 to Rp. 500,000 per vote, while amounts of $\mathrm{Rp}$. 750,000 to $\mathrm{Rp}$. 1,000,000 were reported on social media. This news spread rapidly and clearly influenced the opinions and behaviours of voters in facing the election.

Reports from the field indicate that, through their campaign teams, Yasti and Yanni distributed an average of Rp. 200,000/ vote. Meanwhile, although they were reportedly as the 'poor' candidates, Salihi and Jefry were able to distribute Rp. 300,000 for

campaign activities, with attendance ranging from 200 to 1,000 participants. Taking the smallest estimate ( 150 villages multiplied by 200 participants), this gives a minimum of 300,000 participants throughout the region. As such, the amount given for transportation alone reached Rp. 3 billion. This is the smallest estimate, excluding (for example) the cost of the food and drink provided as well as the amount needed to pay for the campaign teams, which informants suggest accounted for 4,000 people. 
their constituents in Dumoga, even only from Jefry's own pocket; nonetheless, they were still unable to compete with their opponents.

Money was distributed simply and openly. Records listed every voter in each household, including students studying outside the regency (Ratih Rintang and Olvi Agow, ibid). Money was also given to voters' parents to distribute when their children were come home. Campaign teams openly asked residents who they would vote for, and then money was distributed to voters the day before the election. Yasti and Yanni's campaign team distributed an average of Rp. 200,000/vote to every voter, (Ratih Rintang and Olvi Agow, ibid; Eko Chandra, interview, February 17, 2017; Fauzi Permata, ibid) while Salihi and Jefry's campaign team distributed Rp. 300,000/ vote, but only in certain areas (Ratih Rintang and Olvi Agow, ibid).

This amount was calculated based on the number of voters who expressed their intention to vote for a candidate, and as such the amount of money received by each household depended on the number of voters within. The more voters living in one household, the more money received. Reports indicated that families received Rp. 800,000, Rp. 1.000.000, or even more (Ratih Rintang and Olvi Agow, ibid; informant, interview, February 27, 2017; Steven Sumolang, interview, March 2, 2017). In some families, some members voted for the Candidate Pair No. 1, while others voted for Candidate Pair No. 2 (Ratih Rintang and Olvi Agow, ibid). As such, families could receive varied amounts of money from the candidates' campaign teams. As such, some residents not only provided their support, but seemingly gambled to see who would provide the greatest amount of money.

Multiplying Rp. 200,000 by 100,000 votes, it can be calculated that a total of Rp. 20 billion was distributed by Yasti and Yanni alone on malam bakupas. ${ }^{11}$ Rumours suggest that Yasti spent at least Rp. 40 billion during the regional election; this is aside from the

This amount was also confirmed in an interview with Abdul Kadir Mangkat, February $28,2017$. 
money spent by Yanni and Candidate Pair No. 2. ${ }^{12}$ Seeing how the local political machine was mobilised and money was distributed during the campaign, this amount is not surprising. However, the demographic, political, and financial situation in Bolaang Mongondow would suggest that this amount is excessive-especially for one candidate.

Meanwhile, the rampant practice of money politics is evidenced by its wide recognition in local society. It occurred at all levels, both among the civil population and among election officials (campaign teams, election commission members, election monitors, and even the police). As such, there was no fear of any potential legal repercussions; everything could be bought. At the lowest level, between recipients and distributors, money was given without an envelope, showing the openness of the process. As many locals stated, "everyone already knew" (Junaidi Amra, ibid; Pitres Sombawadile, ibid). ${ }^{13}$ Meanwhile, the monitoring team (informant, interview, February 27, 2017) noted that campaign teams would report their opponents' misdeeds, including their distribution of money, (ibid). ${ }^{14}$ but no legal measures were ever undertaken (ibid; informant, interview, Januari 30, 2017).

Campaign teams had clearly considered legal issues such as these, as they recognised that vote buying had become widely accepted, rather than perceived as a crime. Campaign teams used a simple yet effective managerial approach to distributing money, one which enabled them to avoid being entangled in legal issues should their vote buying be challenged. This approach was similar to that used in Multi-Level Marketing, with the regency coordinator controlling the district coordinators, and these district coordinators in turn controlling the village coordinators tasked with distributing money to candidates. This standard approach was applied effectively

\footnotetext{
Ibid.

Original: samua so baku tahu.

Also based on data from the Elections Agency of Bolaang Mongondow.
} 
in Bolaang Mongondow. Where evidence of cheating was found, the 'chain' was severed at that level, rather than being followed to higher levels. Even among the elites, this situation was consciously and openly recognised, as confirmed by statements by Sehan Landjar: there would be no problem if it could not be proven (Sehan Beri Selamat, 2017).

\section{(Cross) Bureaucracy Movement and Vote Buying}

One major political phenomenon found in North Sulawesi was the massive mobilisation of bureaucratic networks and their resources to gain political support (Sumampouw, 2016a, p. 321, 340). However, this was not a hallmark of the incumbent's campaign, but rather that of Yasti and Yanni; this pair of candidates did not only use the bureaucracy and resources in Bolaang Mongondow, but also those of Kotamobagu and North Sulawesi, whose government heads were allied with Yasti. This bureaucratic movement was confirmed through an interview with the Deputy Mayor of Kotamobagu, the Head of the General Election Commission of Kotamobagu, and the Head of the Bolaang Mongondow Election Monitoring Team:

"Oh, that was certain. Civil servants were mobilised for the regional election in Bolaang Mongondow. That's undeniable." (Nayodo Kurniawan, ibid; Jainuddin Damopolii, February 24, 2017; interview, March 2, 2017; Steven Sumolang, ibid; Daendels Sombowadile, interview, March 2, 2017; Jefry Tumelap, interview, March 3, 2017).

Salihi and Jefry received the support of several regional executives from Golkar, but this was primarily based in a shared party affiliation, rather than the massive mobilisation of the bureaucracy. There were reports that Tetty Paruntu (the Golkar Chairperson for South Minahasa), Vreeke Runtu (the Golkar Chairperson for North Sulawesi), and Marlina Moha-Siahaan (former regent of Bolaang Mongondow) participated in campaigning, particularly in Dumoga. In her campaigning, Tetty was reported to have distributed resources to churches in Dumoga. However, this was at a much smaller scale 
and more sporadic than practiced by Yasti and Yanni.

Bureaucratic support for Yasti and Yanni was clear from the end of Regent Salihi Mokodongan's term. The naming of Nixon Watung as acting regent by Governor Olly Dondokambey implied a political alliance between him and Yasti, and his political party PDIP was undoubtedly the first to back Yasti's candidacy. Yasti and Olly were known for having a long-standing relationship and political alliance, even when their parties were not allied at the national level (Sumampouw 2016b). Many informants expressed the view that the selection of Nixon Watung, a provincial bureaucrat, as acting regent was a strategy to provide support for Yasti through the bureaucracy (Steven Sumolang, Januari 24, 2017; interview, January 24, 2017; Pitres Sombowadile, ibid; Daendels Sombowadile, ibid). Over time, the leaders of the various departments, agencies, districts, and villages in Bolaang Mongondow were replaced to reach a political goal, (Steven Sumolang, ibid; interview, January 24,2017 ) as was the regional secretary (Wolajan, 2017; Pansel Sekkab, 2017). The governor, acting regent, as well as several district chiefs and bureaucrats were recorded as openly attending some of Yasti's campaign activities, in violation of standing rules. This was reported to the election monitoring team of Bolaang Mongondow, and created significant political tension. Through mediation, led by the police and monitoring team, it was shown that political and bureaucratic networks at the provincial level had become involved in the election. As such, it was said that "the acting regent offered himself for Yasti." (informant, interview, January 24, 2017). ${ }^{15}$

From the above discussion, it can be seen that the regional bureaucracy, because of the simultaneous elections, was open to hijacking — or mobilisation — by alliances and political considerations at the provincial level. According to current laws, the selection of acting regent is to be done by the governor. Although the previously elected regent finished his term in mid-2016, elections were not

15 Original: Penjabat Bupati pasang badan untuk Yasti. 
held immediately; rather, an acting regent was chosen to serve until simultaneous elections were held in 2017. As such, the governor gained access to strategic resources and the regional budget, enabling him to prepare a structure that supported his candidate. In this, the support of the governor (openly, through party mechanisms) was granted fully to Yasti.

Meanwhile, the coordinator of Yasti's campaign team, Ismail Dahab, was not allied with any political party (Ismail Dahab, ibid). He was known as a direct extension of Yasti, and through his influence he was able to inform the selection of acting regent in Bolaang Mongondow and acting mayor in Kotamobagu, including the political strategies used to gather bureaucratic resources (both money and programmes) (Steven Sumolang, March 6, 2017; informant, interview, March 8, 2017). The major political, social, and bureaucratic actors in Bolaang Mongondow would refer to him regarding Yasti's strategies, policies, and political decisions. As such, despite being the incumbent, Salihi Mokodongan had no political access within the (Greater) Bolaang Mongondow bureaucracy. If he did have any access, it was extremely limited.

This influenced various political processes in the Bolaang Mongondow elections, including government programmes, and indirectly shaped the budget to ease Yasti's election. Civil servants, as well as their families, were urged to support Yasti. This was not only seen as a response to Yasti's perceived control of the government, but also involved 'threats'. After the votes were tallied and Yasti was named regent, she stated that, upon inauguration, she would immediately ask for the resignation of all officials who did not share her vision. Civil servants in the region had long known that this would occur, and felt the need to take action. As thus, vote buying can be seen not only as involving the distribution of materials, but also abstract promises or threats.

The mobilisation of civil servants in Bolaang Mongondow was not limited to gathering votes for Yasti, but also included distribution of her campaign's money. Reports from Dumoga 
indicated that the 'dawn attacks' were not only perpetrated by village or district officials, but also village secretaries; (Ratih Rintang and Olvi Agow, ibid) this was widely reported from regions along the northern coast. These secretaries were tasked with gathering the civil servants, and thus could control the political situation in this smallest of administrative units. As such, whoever had access to the regional bureaucracy also had access to the structural and financial resources of these secretaries.

The bureaucracy's support for Yasti and Yanni also had structural implications for the regional budget, as vote buying was handled through bureaucratic resources. Government programmes, such as investment development, cooperatives, minimum wage, and housing, were promoted as having been created by Yasti. Furthermore, after the election, Yasti and Yanni were supported by the purchase of official cars through the regional budget which initiated by acting regent (Wolajan, 2017; Dahar, 2017).

Political alliances were created not only with bureaucrats at the provincial level, but also with those in Kotamobagu. The deputy mayor, as well as the head of the regional elections commission, explained that there was a massive mobilisation of civil servants in Kotamobagu during the Bolaang Mongondow election to ensure that they voted for Yasti and Yanni, (Nayodo Kurniawan, ibid; Jainuddin Damopolii, ibid) as noted in the following quote:

"My older sibling was sent there, received a notice, to go to Bolaang Mongondow to observe the elections process and secure votes or urge voters to choose Candidate Pair No. 1." (Informant, interviews, February 27, 2017; informant, interview, March 3, 2017). ${ }^{16}$

This clearly did not only involve structural commands, but also formal delegations and the allocation of Kotamobagu's financial and bureaucratic resources for political purposes in

16 Original: Kakak saya pergi ditugaskan dan mendapat surat tugas, SPPD ke Bolaang Mongondow untuk melihat proses Pilkada sekaligus mengamankan atau membujuk pemilih untuk memilih Paslon 1. 
Bolaang Mongondow, i.e. to gather support for Yasti and Yanni. From several testimonies, it is evident that almost all civil servants in Kotamobagu whose hometowns were administratively part of Bolaang Mongondow were urged to return to their villages, with the goal of collecting support for Candidate Pair No. 1. Elsewhere, it was reported that the head of the human resources section in Kotamobagu distributed material goods to constituents in Bolaang Mongondow.

This has confirmed that vote buying in the 2017 Bolaang Mongondow regional election required extensive political resources, which could not be supplied through candidates' personal networks alone; they required bureaucratic alliances with people administratively not (only) within their own constituencies.

\section{Source of Funding for Vote Buying}

Bolaang Mongondow may be considered to lack promise financially, with limited development in its resource and service sectors. In generally, financial movement and circulation has relied primarily on regional projects. The economic opportunities enjoyed by residents are limited. Very few large companies exist in the regency, and their economic and political influence is doubtful. As such, these companies and investors involved had limited potential for fully funding vote-buying activities.

However, the rationale for using vote buying can be seen from the profiles of the four Regent/Deputy Regent candidates, as well as the key political figures in the region-most of whom are in business. Yasti, for instance, is known as a contractor who has benefited through her position as a public official (Fauzi Permata, ibid). Furthermore, as the former treasurer of the central PAN committee and head of the Commission V (infrastructure budgeting, including partnerships with the Ministry of Public Works and Ministry of Transportation), she has clear access to financial support in this field. She is also known as having stock 
in the airline Lion Air, as being close to the airline's owner Rusdi Kirana, a former member of Presidential Advisory Council and now serve as an Ambassador in Malaysia (Fauzi Permata, ibid). Yasti also owns a number of restaurants in Bolaang Mongondow and Manado, as well as a large ginger plantation who has networks with Sido Muncul and a number of contractors under her family's control. (Fauzi Permata, ibid) Yasti was reported to be the second richest candidate in the simultaneous elections, after Sandiaga Uno, with a personal wealth of approximately Rp. 2.27 trillion (Menyoal Rekening, 2017). Although her campaign team claimed her personal wealth was Rp. 24 billion, (Ismail Dahab, ibid; Fauzie Permata, ibid) an examination of her business networks and strategic positions in parliament and PAN, a figure of Rp. 2.27 trillion is more believable (Fauzi Permata, ibid). Rumours also suggested that Yasti could potentially be charged with corruption for her activities as a member of parliament, particularly while leader of the Commission V and treasurer of the central PAN committee (Yasti Masuk, 2016; Yasti Dalam, 2017; Menyoal Rekening, 2017). She had previously faced investigation for her activities in projects funded by the Ministry of Public Works and Ministry of Transportation (Bendahara PAN, 2012; KPK Periksa, 2012; Laluhu, 2016).

Yasti's running mate, Yanni Tuuk, was the head of PDIP's regional branch, and owned a mining company in Dumoga, expansive rice fields, and several properties in Manado (Fauzie Permata, interview, March 1, 2017). His wife and sibling are members of the regency and provincial parliaments, respectively, with PDIP, positions that they gained in the last legislative election in part because of Yanni's influence (Sumampouw, 2016b). Yanni has direct access to financial assistance in the name of the party, through the party's patron: Governor Olly Dondokambey. Despite the political alliance with the head of the Bolaang Mongondow parliament, (informant, interview, March 2, 2017; Steven Sumolang, March 2, 2017; informant, interview, February 27, 2017) it is clear that Yasti remained the dominant candidate and Yanni being 
selected with his limited financial support in the election.

Meanwhile, Salihi Mokodongan operates a fishery on the north coast of Bolaang Mongondow, and has been confirmed to owe a debt of Rp. 10 billion to Yasti, (Abdul Kadir Mangkat, ibid; Pitres Sombowadile, ibid) ${ }^{17}$ money he used to win the previous regional election. Shortly after Salihi formally announced his candidacy, his assets were seized, (Ini Aset Salihi, 2017; Penyitaan Aset, 2017) which is difficult to consider a simple matter of debt without any political implications. It was reported that, shortly before voting, Salihi received a call from Yasti, and this was one reason for him seeming doubtful and apparently giving victory to Yasti, including by limiting his political spending (Salihi Pilih, 2017; Abdul Kadir Mangkat, ibid; Jefri Tumelap, March 3, 2017; Fauzie Permata, ibid). Yasti's campaign team claimed that Salihi's debt to Yasti was simply a debt to Muhammad Wongso, her brother-in-law, which emerged as a result of normal business interactions (Ismail Dahap, ibid). With the backing of PAN, Muhammad Wongso had become the first Muslim member of the Manado parliament from the Sario-Malalayang constituency. He was also reported to have mounted 'dawn attacks' on a massive scale, using rice and money in the amount of Rp. 200,000/vote (Sumampouw, 2016b). As such, it is difficult to deny that the strong flow of money originated from Yasti.

Salihi's running mate, Jefry Tumelap, is the head of the regional Demokrat branch in Bolaang Mongondow, a member of the regency parliament, and known for his successful contract work in Papua. He also owns property in Papua and Manado. Salihi and Jefry's campaign relied primarily on the financial and material resources of the latter (Daendels Sombowadile, ibid; Steven Sumolang, ibid; informant, interview, March 2, 2017; Abdul Kadir Mangkat, ibid). Reports indicate that Jefry was disappointed by Salihi's tendency to not contribute money to the political process; he felt that, although

17 See also the news reports following. 
he had spent billions of rupiah, (informant, interviews, March 2, 2017; Daendels Sombowadile, ibid; Steven Sumolang, ibid) he had not gained any financial support from Salihi.

From these profiles, it can be seen that, as the capital from companies in Bolaang Mongondow remains limited, the money used by candidates instead comes from their own pockets.

There is a tendency for this region to be seen as a potential economic 'asset', as broad expanses of land are available and large companies are limited. There are indications that candidates seek to become regent/deputy regent in order to access policymaking, such as through the granting/facilitation of permits for using land, establishing company, and managing strategic national projects.

There is little potential for candidates from such economically isolated regions to receive direct funding from mining companies and plantations in exchange for specific concessions from the successful candidates, especially since authority for such policymaking is held at the provincial level. Rather, the potential yet underdeveloped resources and infrastructure may actually offer an opportunity to 'sell' their region to investors. With their victory, this opportunity went to Yasti and Yanni. Infrastructure development projects, particularly the Pindol Dam and regional airport, have benefited Yasti, who has enjoyed direct access to national and multi-national companies both through her experiences with Commission $\mathrm{V}$ and her networks. This was only reinforced when, shortly after being inaugurated as regent, Yasti stopped all operations of the cement company PT. Conch, which was located on land intended to be developed into the Bolaang Mongondow Airport; this brought her legal trouble (Pontororing, 2017). PT. Semen Conch had been legalised and facilitated under Yasti's opponent, Salihi Mokodongan, despite opposition from Yasti (Gubernur diminta, 2016).

Another opportunity emerged from the rationalisation for using personal money for political purposes through the giving of concessions and land usage rights. Yasti enjoyed a close relationship with Olly Dondokambey, the incumbent governor, as well as 
General Treasurer of PDIP, former head of the Commission XI (Budgeting), and former Deputy Chair of the Budget Agency. Meanwhile, her deputy, Yanni Tuuk, had direct access through his party ties to the governor, who had the authority to grant land usage rights and concessions within North Sulawesi, including in Bolaang Mongondow.

\section{Conclusion: A Theoretical and Empirical Comparison}

In the case of Bolaang Mongondow, several views should be noted regarding vote-buying as a system underlying political movements, including its position in social and societal perspectives and structures. As a phenomenon within a democratic political system, the case of Bolaang Mongondow reinforces the argument (Aspinall et al., 2017, p.23) that vote buying can be more successful using the social networks machine. ${ }^{18}$ As such, the argument that relatively mature parties can better distribute money in vote buying (Brusco et al., 2004; Aspinall et al., 2017, p23) must be questioned. In the case of Bolaang Mongondow, the structures of the parties backing the candidates did not function, while social networks machines and the bureaucracy offered more promising opportunities for mobilisation.

Regarding bureaucracy, the case of Bolaang Mongondow also offers perspective, as Yasti-who most effectively mobilised the bureaucracy in her vote buying activities - was not an incumbent. The incumbent advantage (Cruz, et al., 2016; Hicken et al, 2016; Serra, 2016) thus deserves criticism, as the most important factor is not incumbent status but rather access to bureaucracy. In Bolaang Mongondow, Yasti had access to the governor through a political alliance, which offered her a means of influencing the regional budget

18 The term social network machine is quoted from Aspinall et al. (2017. P. 23). According to Aspinall et al., in Indonesia the social networks machine has been used for political interests such as accessing family, friendship, and alumni networks, as well as student organisations. This approach has been seen as more effective than conventional political machines such as parties. 
and use of the bureaucracy to distribute money to voters to support of her campaign. Such access to resources at the provincial level was possible because the regulations regarding simultaneous elections gave the acting regent-selected by the governor-sufficient time to influence the bureaucracy and prepare resources for the candidate supported by his boss, i.e. the governor. In other words, regulations for simultaneous elections enabled the bureaucracy at the regency/ municipal level to be 'hijacked' by the political interests of the provincial government.

Furthermore, the buying of votes through the bureaucracy indicates that different government elements can potentially be connected, not only within the regency itself, but also with different regional governments and the provincial bureaucracy; particularly strong influence came from the Kotamobagu government, which mobilised its own civil servants for political interests. In studies of vote buying, the question of distribution-particularly across different bureaucracies - has yet to be examined much. Most studies have focused solely on the incumbent advantage through which candidates gain access to resources (i.e. Cruz, et al., 2016; Hicken et al, 2016; Serra, 2016).

Meanwhile, the view that vote buying is illegal (Serra, 2016; Aspinall, 2017, p.3) and practiced only furtively, widespread in Indonesia, was not found in Bolaang Mongondow. Instead, in this regency vote buying has been practiced openly at all levels of society and even among election officials. In distributing money, candidates have not used envelopes, which may indicate symbolically the openness of the process. As a consequence of this, in Bolaang Mongondow concern has not focused on the furtive practice of vote buying, but whether it can be legally proven and prosecuted. As such, it is accurate to argue that the practice of vote buying is socially accepted in Indonesia (Muhtadi, 2015 as cited in Aspinall, et al., 2017, p. 6). This has also occurred in Bolaang Mongondow, even more openly than in other parts of the country. As such, legal issues and social perspectives are positioned as more important than 
the democratic system and elections.

Furthermore, as explained above, the 'multi-level' structural model of the campaign teams, as well as the involvement of provincial bureaucrats, ensure that any legal proceedings will stop before spreading further. This appears to be a weakness of the election coordination system in Indonesia, which has enabled provincial political interests to intervene in the domestic political affairs of regencies and municipalities.

Demographically, previous studies of vote buying have argued that it is most effective in densely populated regions with high levels of poverty (Diaz-Cayeroz, et al., 2016; Brusco, et al., 2004; Hoepers, 2012; Rojo et al., 2016: Bjorkman, 2013; Serra, 2016; Dewi, et.al., 2016). This was not evidenced in the case of Bolaang Mongondow, which has a low population density and whose residents are relatively self-subsistent. As such, in Bolaang Mongondow social perspectives have been far more influential in maintaining or legitimizing vote buying than economic composition and structure. 


\section{References}

Aspinall, E., \& Sukmajati, M. (Eds.) (2015). Politik uang di Indonesia; Patronase dan klientelisme pada Pemilu Legislatif 2014. Yogyakarta: PolGov.

Aspinall, E., \& Sukmajati, M. (Eds.) (2016). Electoral dynamics in Indonesia; money politics, patronage and clientelism at the grassroots. Singapore: NUS Press.

Aspinall, E., Rohman, N., Hamdi, A., Rubaidi, \& Triantini, Z. (2017). Vote buying in Indonesia: Candidate, strategies, market logic and effectiveness. Journal of East Asian Studies, 17(1), 1-27. doi:10.1017/jea.2016.31

Bendahara PAN diperiksa Soal Proyek Rp. 1 Triliun. (2012, November 20). Media Indonesia. Retrieved from http://kpk.go.id

Björkman, L. (2013). You Can't Buy a Vote: Cash and community in a Mumbai election. MMG Working Paper, 13 (01). Max Planck Institute for the Study of Religious and Ethnic Diversity, Gottingen.

Brusco, V., Nazareno, M., \& Stokes, S.C. (2004). Vote buying in Argentina. Latin American Research Review, 39 (2), 66-88.

Cruz, C., Keefer, P,. \& Labonne, J. (2016). Incumbent advantage, voter information, and vote buying. IDB Working Paper Series No. IDB-WP-711. Inter-American Development Bank; Institution for Development Sector.

Dahar, J. (2017, February 10). Randis 800 juta untuk Bupati baru. Manado Post, p.21.

Deslatama, Y. (2017, February 9). Bawaslu hentikan pengusutan politik uang di pilkada Banten. Liputan 6.com. Retrieved from http://m. liputan6.com

Dewi, S.W., Harjanto, S.L., \& Purba, O.D. (2016). Central and South Jakarta: Social welfare and constituency service in metropolis. In Aspinall, E., \& Sukmajati, M. (Eds.). Electoral Dynamics in Indonesia: Money Politics, Patronage and Clientelism at the Grassroots. (pp. 167-183). Singapore: NUS Press.

Diaz-Cayeros, A., Estévez, F., \& Magaloni, B. (2016). The political logic of poverty relief: Electoral strategies and social policy in Mexico Cambridge: Cambridge University Press.

Eyang sebut Ismail dahapo money politik pilkada Boltim (2015, December 22), Totabuannews Retrieved from https://totabuannews. com $/ 2015$ 
Gubernur diminta hentikan kegiatan PT Conch. (2016, August 26). Media Sulut. Retrieved from http://mediasulut.co

Hamja, B. (2017, February 14). Per Suara dibandrol Rp. 200-500 ribu. Radar Bolmong, pp.1 \& 15.

Hicken, A.D. (2007). How do rules and institutions encourage vote buying?. In Schaffer, F. (Ed.). Elections for Sale: The Causes, Consequences, and Reform of Vote Buying. (pp. 47-60). Boulder: Lynne Reiner.

Hicken, A., Leider, S., Ravanilla, N., \& Yang, D. (2016). Temptation in vote-selling: Evidence from a field experiment in the Philippines. Manuscript submitted for publication.

Hoepers, B. (2012). The determinants of vote buying in Brazil: Taking contextual factors into account. Unpublished Document. Fuente: University of Pittsburgh.

Ini aset Salihi disita PN Kotamobagu. (2017, February 1). Totabua News. Retrieved from https://totabuanews.com

KPK periksa Yasti Soeprejo Mokoagow. (2012, November 19). Berita Kawanua. Retrieved from http://beritakawanua.com

Laluhu, S. (2016, March 24) KPK incar 9 anggota komisi V DPR di kasus suap PUPR. Sindo News. Retrieved from https://nasional. sindonews.com

Menyoal rekening gendut Yasti (2017, February 1,). Koran Bolmong, pp.1 $\& 11$.

Norma akan ambil pemberian calon (2017, February 11). Tribun Manado, p.13.

Pansel Sekkab definitif dibentuk (2017, February 7), Manado Post, p.21.

Penyitaan aset milik Salihi oleh PN Kotamobagu dihalangi warga. (2017, February 2). Metro, p.10.

Pilkada Bolaang Mongondow PAN ada didua kubu (2017, January 23), Radar Manado, p.6.

Politik uang tanah jawara. (2017, February 19). Majalah Tempo, pp.48-50.

Pontororing, M. (2017, June 20). Kasus pengrusakan TP Conch Polda periksa Bupati Bolmong. Metro TV News. Retrieved from http:// news.metrotvnews.com

Rojo, G., Jha, S., \& Wibbels, E. (2016). Political networks, clientelism, and public goods: Evidence from Slums in Udaipur, India. Working Paper.

Salihi pilih kembali melaut. (2017, February 24). Tribun Manado, pp. 1 
$\& 7$.

Sehan beri selamat kepada Yasti-Yanni (2017, February 16). Tribun Manado, p. 13.

Serra, G. (2016). Vote buying with illegal resources: Manifestation of a weak rule of law in Mexico. Journal of Politics in Latin America, 8 (1), 129-150.

Sumampouw, N.S.A. (2016a). North Sulawesi: Clan, church and the state. In Aspinall, E., \& Sukmajati, M. (Eds.). Electoral Dynamics in Indonesia: Money Politics, Patronage, and Clientelism at the Grassroots. Singapore: NUS Press. pp. 321-340.

Sumampouw, N.S.A. (2016b). Visi, misi, pici, gizi, ruci: Cultural roots within vote buying practices in the 20141 election (Case of North Sulawesi, Indonesia). Paper presented at the International Conference "From Clients to Citizen? Citizenship in Democratising Indonesia”. Yogyakarta, 8-10 December 2016.

Wolajan, F. (2017, February 8) 20 Pejabat Bolmong layak perebutkan kursi Sekda. Tribun News. Retrieved from http://manado.tribunnews. com

Wolajan, F. (2017, February 9) Pemkab Bolmong siapkan dana Rp. 1,5 Miliar untuk beli mobil baru. Tribun News. Retrieved from http:// manado.tribunnews.com

Yasti dalam pusaran korupsi. (2017, January 12). Koran Bolmong, pp. 1 $\& 11$.

Yasti masuk incaran KPK. (2016, December 22). Koran Bolmong, pp. 1 $\& 11$. 